\title{
Stress and Uterine Bacterial Flora in Dairy Cows Following Clinically Normal and Abnormal Puerperium
}

\author{
Eduardo B. TORRES ${ }^{2)}$, Toshihiko NAKAO, Takashi HIRAMUNE1), \\ Masaharu MORIYOSHI, Keiichiro KAWATA and Ken NAKADA \\ Departments of Veterinary Obstetrics and Gynecology, and \\ 1) Epizootiology, School of Veterinary Medicine, \\ Rakuno Gakuen University, Ebetsu, Hokkaido 069, Japan and \\ ${ }^{2)}$ Department of Veterinary Clinical Sciences, College of Veterinary Medicine, \\ University of the Philippines at Los Baños, College, Laguna 4031, Philippines
}

\begin{abstract}
ACTH challenge tests for the assessment of stress on the first and third week postpartum and bacteriologic examination of uterine swabs on the second and fourth week, were conducted in dairy cows following clinically normal $(n=12)$ and abnormal $(n=21)$ puerperium. Postpartum ovarian activity and uterine involution were also investigated. The basal plasma cortisol concentrations (mean \pm S.E.) during the first and third week postpartum were $3.1 \pm 0.9 \mathrm{ng} / \mathrm{ml}$ and $3.4 \pm 1.1$ $\mathrm{ng} / \mathrm{ml}$ in normal cows, and $6.5 \pm 1.9 \mathrm{ng} / \mathrm{ml}$ and $4.9 \pm 1.2 \mathrm{ng} / \mathrm{ml}$ in abnormal cows, respectively. The mean basal plasma cortisol values of abnormal cows were elevated and significantly higher $(\mathrm{P}<0.05)$ during the first week postpartum. Bacterial organisms were isolated from the uterus of $33.3 \%$ of normal and $61.9 \%$ of abnormal cows during the second week postpartum and in $33.3 \%$ of normal and $23.8 \%$ of abnormal cows during the fourth week. Resumption of ovarian activity was neither affected by puerperal disorders nor uterine bacterial infection. Uterine involution at 4 weeks postpartum was completed in all cows with normal puerperium and delayed in $23.8 \%$ of abnormal cows. The results indicate that cows with abnormal puerperium had significantly higher basal cortisol levels, and had higher occurrence of uterine bacterial infection during the second week when compared with normal cows.
\end{abstract}

Key words: Stress, Uterine infection, Puerperium, Cows.

(J. Reprod. Dev. 43: 157-163, 1997)

$\mathbf{P}$ uerperal complications such as dystocia, retained placenta and milk fever in dairy cows are considered as stressful conditions that influence the subsequent reproductive function. Stress is believed to cause the synthesis and release of adrenal glucocorticoids [1] which are capable of markedly diminishing an animal's defense against infection [2]. Glucocorticoids may increase the susceptibility of the uterus to infection through their

Accepted for publication: March 25, 1977

Correspondence: E. B. Torres anti-inflammatory actions [3]. It has been further reported that if the defense mechanisms of the reproductive tract are impaired or weakened, bacteria may colonize in the uterus and lead to the development of uterine infection [4]. The bacterial content of the postpartum bovine uterus had been described in numerous studies [5-13]. The cortisol levels in the peripheral blood had also been accepted as a reliable physiological endpoint for determining response to stress or to any disease of the adrenal cortex [1]. However, no study has ascertained the degree of stress and uterine bacterial 
contamination in postpartum dairy cows. In this study, the degree of stress and the uterine bacterial flora in dairy cows following clinically normal and abnormal puerperium were investigated. Possible effects of abnormal puerperium and uterine bacterial infection on ovarian activity and uterine involution were also evaluated.

\section{Materials and Methods}

A total of 33 Holstein-Friesian cows from the dairy herd of the Rakuno Gakuen University in Ebetsu, Hokkaido, Japan were used in this study. There were 12 primiparous and 21 pluriparous cows, with ages ranging from 2 to 9 years and a mean of 3.8 years. At calving, the cows were in good nutritional condition, with an average body condition score of 3.3 (1-emaciated; 5-obese), based on the categories described by Weaver [14]. The cows were fed grass silage, hay and concentrates, a ration meeting the nutritional recommendations of the National Research Council [15]. All the animals were kept tied in stanchions and were turned out into an outdoor paddock every morning for $2 \mathrm{~h}$.

Reproductive examinations (visual inspection, vaginoscopy, palpation per rectum and ultrasonography) to determine the presence of postpartum disorder (e.g. dystocia, retained placenta and purulent vaginal or cervical discharges), were performed weekly during the first month after calving. Individual cow health records were also evaluated for the occurrence of other postpartum diseases (e.g. milk fever and fatty liver disease). The degree of uterine involution was determined according to criteria adapted from Buch et al. [16] and Johanns et al. [17]. Gross uterine involution at 30 days postpartum was described as normal when the uterine horns were located on the pelvic floor, had equal or similar size, were $4 \mathrm{~cm}$ or less in diameter, and had normal tone and consistency.

The degree of stress in the postpartum dairy cows was determined by measuring the basal cortisol levels and the adrenocortical response to ACTH on the first and third week after calving. Twenty-five i.u. of ACTH (Cortrosyn ${ }^{\circledR}$ Inj., Daiichi Pharmaceutical Co.) were administered intramuscularly. About 5 to $10 \mathrm{ml}$ of blood was collected via coccygeal venipuncture into heparinized test tubes $15 \mathrm{~min}$ and immediately before ACTH injection $(0 \mathrm{~min})$ and $60 \mathrm{~min}$ after the injection. Blood samples were centrifuged at $1,580 \mathrm{~g}$ for $15 \mathrm{~min}$ immediately after collection. The plasma was stored at $-20 \mathrm{C}$ until analysed for cortisol concentrations. Plasma cortisol was determined through a double antibody enzyme immunoassay according to the method described by Nakao et al. [18]. The sensitivity of the enzyme immunoassay was $25 \mathrm{pg} /$ tube. The recovery rate of cortisol in the assay was $105.6 \pm 14.4 \%$. The intra-assay coefficients of variation in plasma with low and high cortisol levels were $7.7 \%$ and $8.8 \%$, respectively. The inter-assay coefficients of variation were $4.5 \%$ and $13.8 \%$, respectively. The criteria for the classification of basal and the type of adrenocortical response to ACTH were adapted from Nakao and Grunert $[19,20]$. In their studies, peak adrenocortical response was observed $1 \mathrm{~h}$ after ACTH injection. The basal cortisol levels were classified as either normal $(<5 \mathrm{ng} / \mathrm{ml})$ or elevated $(\geq 5 \mathrm{ng} /$ $\mathrm{ml}$ ). The type of adrenocortical response to ACTH was defined as: 1) low response if peak cortisol levels were $<15 \mathrm{ng} / \mathrm{ml}, 2$ ) medium response if between 15 and $50 \mathrm{ng} / \mathrm{ml}$, and 3) high response if $>50 \mathrm{ng} / \mathrm{ml}$.

Uterine swabs for bacteriological examination were obtained on the second and fourth week postpartum using a double-sheathed apparatus. In collecting uterine swabs, the culturing technique described by Studer and Morrow [21] was followed. The swab, with its plastic sheath, was immediately brought to the laboratory after collection for routine isolation and identification of aerobic and facultative anaerobic bacteria [22].

Ovarian function, with emphasis on the interval from calving to first ovulation, was evaluated through weekly palpation per rectum and ultrasonographic examination, together with three times weekly milk progesterone levels. Milk progesterone concentrations were determined through a double antibody enzyme immunoassay method described by Nakao et al. [23]. The sensitivity of this assay method was $10 \mathrm{pg} /$ tube. The average recovery rate was $103.7 \%$. The intra-assay and inter-assay coefficients of variation were $0.8 \%$ and $13.2 \%$, respectively. The day of first ovulation was defined as 3 to 4 days prior to the appearance of progesterone levels $1.0 \mathrm{ng} / \mathrm{ml}$ or more [24], together with the ultrasonographic observation of corpus luteum formation.

Statistical analysis of the data consisted of Chisquare test for the comparison of the types of basal 
cortisol levels and adrenocortical response to $\mathrm{ACTH}$, and ANOVA F-test for the cortisol values and the interval to first ovulation.

\section{Results}

Puerperal complications were observed in 21 of 33 cows $(63.6 \%)$. The following postpartum disorders, in descending order, were observed either alone or in combination: purulent vaginal or cervical discharge (18), retained placenta (10), dystocia (2), milk fever (2), vulvar or vaginal laceration (2), pyrexia (2), and fatty liver disease (1). All cases of metabolic disorders were associated with reproductive abnormalities.

The average basal and peak cortisol levels during the first and third week postpartum in cows with normal and abnormal puerperium are shown in Fig. 1. During the first week postpartum, the basal cortisol levels (mean \pm S.E.) in normal and abnormal cows were $3.1 \pm 0.9 \mathrm{ng} / \mathrm{ml}$ and $6.5 \pm 1.9$ $\mathrm{ng} / \mathrm{ml}$, respectively. For the third week, the corresponding values were $3.4 \pm 1.1 \mathrm{ng} / \mathrm{ml}$ and $4.9 \pm$ $1.2 \mathrm{ng} / \mathrm{ml}$, respectively. The cows with abnormal puerperium had elevated and significantly higher

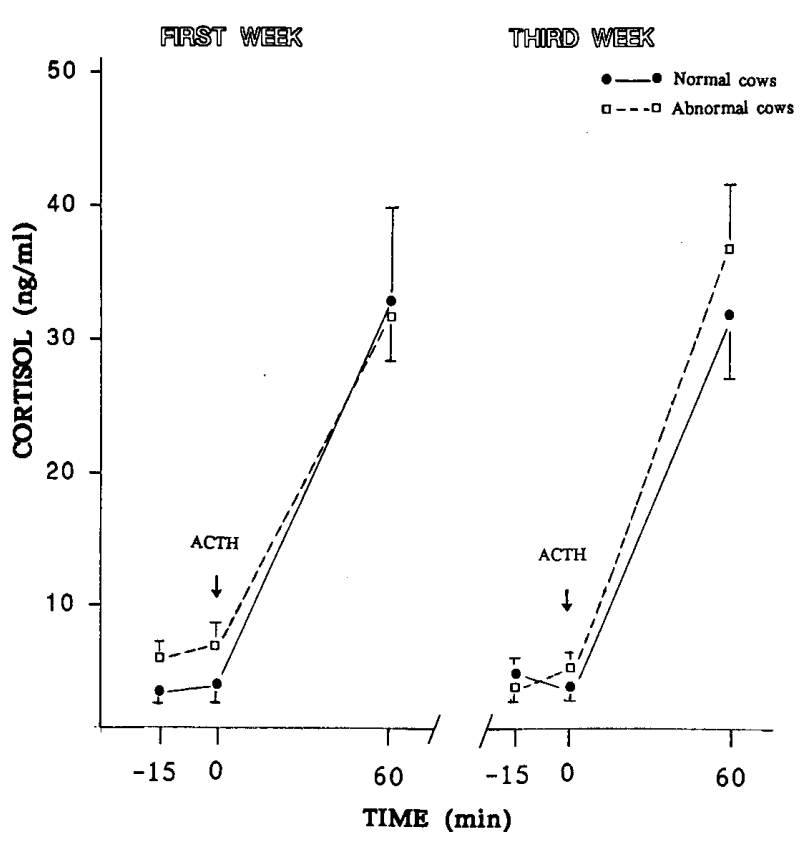

Fig. 1. Adrenocortical response to ACTH during the first and third week postpartum in dairy cows with normal and abnormal puerperium.
$(\mathrm{P}<0.05)$ mean basal cortisol level during the first week postpartum. Further evaluation of the basal cortisol levels showed elevated values in $42.9 \%$ and $33.3 \%$ of abnormal cows, during the first and third week postpartum, respectively. Elevated basal cortisol values were seen in $25 \%$ of normal cows during the same periods. The average peak adrenal responses to ACTH were not significantly different between normal and abnormal cows during the first and third week postpartum.

The examination of the types of peak adrenocortical response to ACTH during the first week postpartum revealed low response in $33.3 \%$, medium in $50 \%$, and high in $16.7 \%$ of normal cows (Fig. 2). For abnormal cows, the respective values were: $19.1 \%, 57.1 \%$ and $23.8 \%$. During the third week postpartum, the peak adrenal responses were low in $25 \%$, medium in $66.7 \%$ and high in $8.3 \%$ of normal cows and for abnormal cows the corresponding
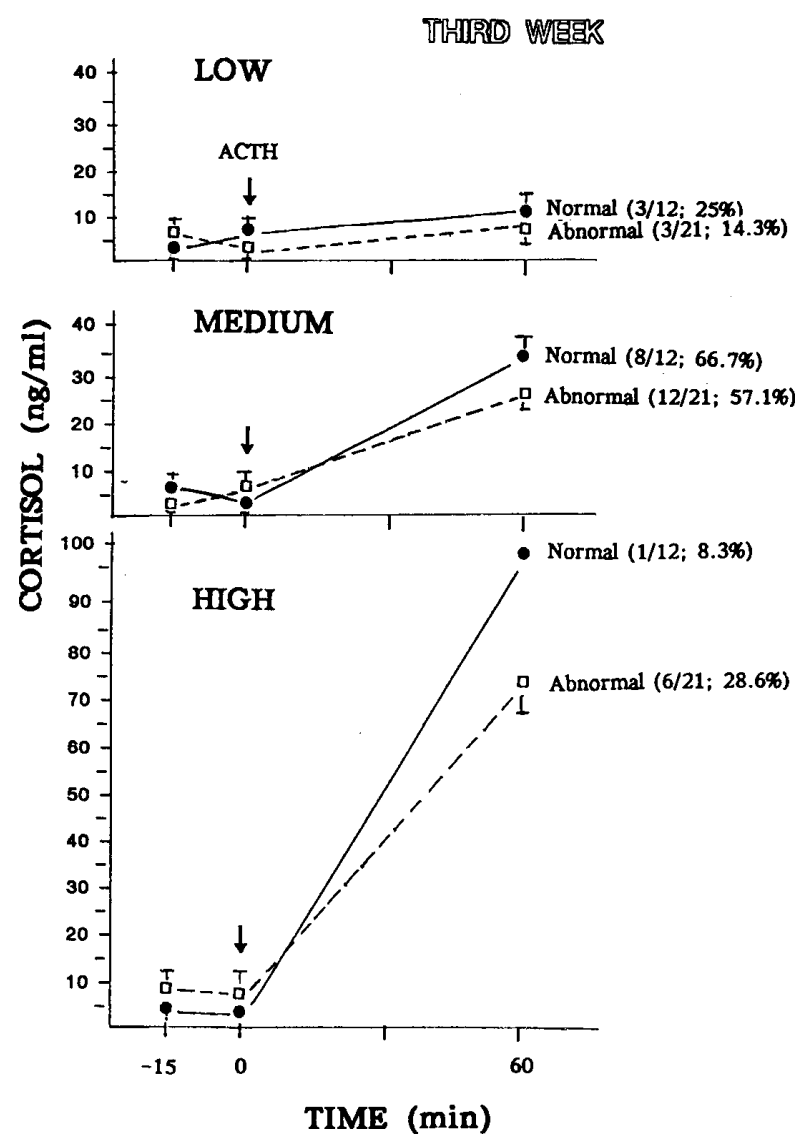

Fig. 2. Types of peak adrenocortical response to ACTH during the first week postpartum in dairy cows with normal and abnormal puerperium. 
values were $14.3 \%, 57.1 \%$ and $28.6 \%$ (Fig. 3). There were more abnormal cows with high peak adrenal response during the first and third week postpartum although this was not statistically significant.

Bacteria were isolated from the uterus of 21 $(63.6 \%)$ of 33 postpartum cows. The bacteria isolated during the two sampling periods from the uterus of normal and abnormal cows are shown in Tables 1 and 2, respectively. On the second week postpartum, 4 of $12(33.3 \%)$ normal and 13 of 21 $(61.9 \%)$ abnormal cows were found positive for bacterial isolates. While on the fourth week, 4 of $12(33.3 \%)$ normal and 5 of $21(23.8 \%)$ abnormal cows were positive. The three common bacterial isolates from the uterus were Actinomyces pyogenes, Streptococcus spp. and Escherichia coli. It was also noted that the most common bacterial isolate $(45 \%)$ from cows with purulent vaginal or cervical discharge was Actinomyces pyogenes.
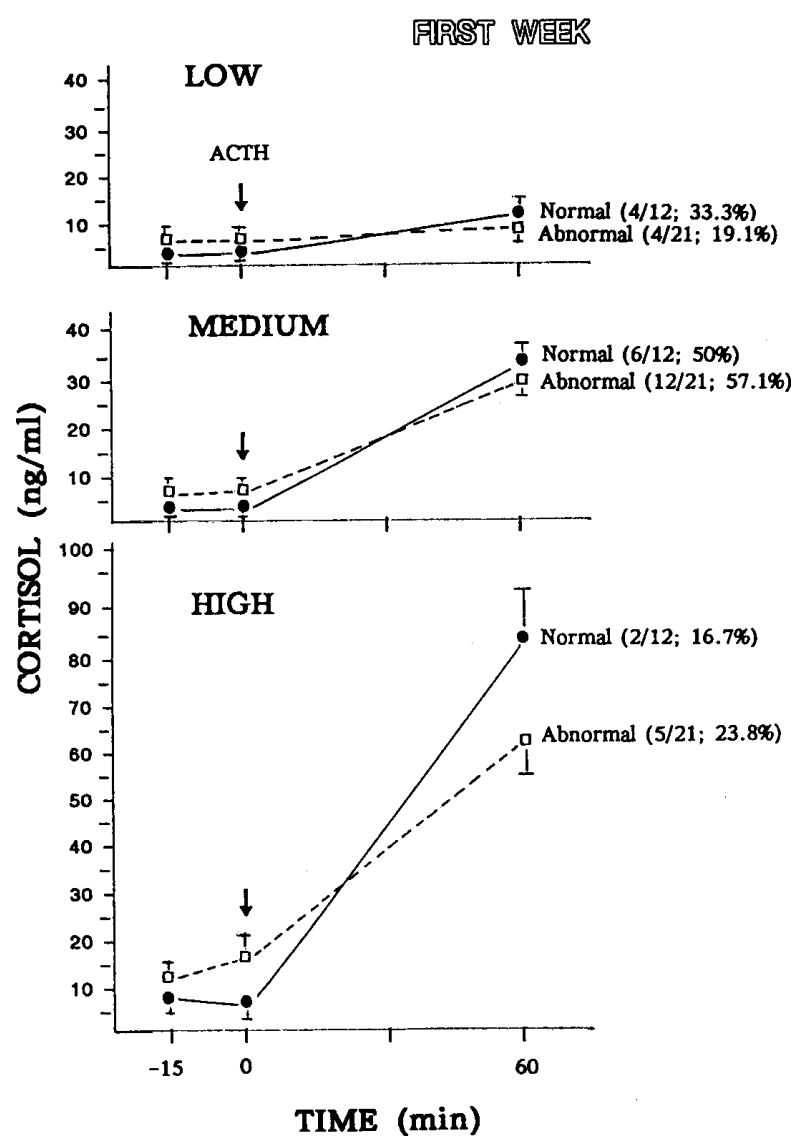

Fig. 3. Types of peak adrenocortical response to ACTH during the third week postpartum in dairy cows with normal and abnormal puerperium.
Evaluation of the interval to first ovulation (mean \pm S.E.) showed no significant difference for cows with normal (17.9 \pm 1.9 days) and abnormal (18.7 \pm 1.6 days) puerperium. At 4 weeks postpartum, uterine involution was found to be normal in all the cows $(100 \%)$ with normal puerperium, while in cows with abnormal puerperium, 5 cows $(23.8 \%)$ had delayed uterine involution.

\section{Discussion}

In the present study, a greater degree of stress in cows with abnormal puerperium were shown by the elevated and significantly higher mean basal cortisol levels during the first week postpartum. Further classification of the basal cortisol levels into normal and elevated, and the peak adrenocortical responses to ACTH into low, medium and high also showed the tendency for cows with abnormal puerperium to have more cases with high cortisol values during the first and third week postpartum. Most studies on adrenocortical function in postpartum cows showed highest cortisol values at the time of calving and a return to basal values by 0.5 to 3 days postpartum [25-27]. It was sug-

Table 1. Bacteriological findings in uterine swabs of dairy cows with normal puerperium $(n=12)$

\begin{tabular}{lcccr}
\hline \multirow{2}{*}{ Bacteria } & \multicolumn{2}{c}{ No. of isolates } & & Total No. \\
\cline { 2 - 3 } & 2nd wk. & 4th wk. & & \\
\hline Streptococcus spp. & 1 & 3 & 4 & 36.4 \\
Escherichia coli & 2 & 1 & 3 & 27.2 \\
Actinomyces pyogenes & 2 & 0 & 2 & 18.2 \\
Pseudomonas aeruginosa & 0 & 1 & 1 & 9.1 \\
Bacillus spp. & 0 & 1 & 1 & 9.1 \\
\hline
\end{tabular}

Table 2. Bacteriological findings in uterine swabs of dairy cows with abnormal puerperium $(n=21)$

\begin{tabular}{lccrrr}
\hline \multirow{2}{*}{ Bacteria } & \multicolumn{3}{c}{ No. of isolates } & & \\
\cline { 2 - 3 } & 2nd wk. & 4th wk. & & \\
\hline Actinomyces pyogenes & 7 & 3 & 10 & 45.4 \\
Streptococcus spp. & 3 & 1 & 4 & 18.2 \\
Escherichia coli & 2 & 1 & 3 & 13.6 \\
Proteus mirabilis & 2 & 0 & 2 & 9.1 \\
Enterococcus faecalis & 1 & 0 & 1 & 4.5 \\
Micrococcus spp. & 1 & 0 & 1 & 4.5 \\
Proteus vulgaris & 1 & 0 & 1 & 4.5 \\
\hline
\end{tabular}


gested that except for the surge at calving, plasma concentrations of glucocorticoids did not differ between late gestation and early lactation and that there was no modification in adrenal responsiveness [27]. However, several studies on cows with dystocia reported cortisol concentrations that were higher than the average value during normal parturition [26, 28]. Nakao and Grunert [20] investigated the adrenocortical response in cows with dystocia and found that on day 1 postpartum, those that required caesarean section after unsuccessful extraction or total fetotomy had higher basal and ACTH-stimulated plasma cortisol concentrations than those in cows with normal parturition.

Several researchers reported that from $85 \%$ to $96 \%$ of the bovine uteri contained bacterial flora in the early postpartum period $[5,6,17]$. The lower occurrence found in the present study is closer to that reported by Fredriksson et al. [9] who found $49 \%$ of the cows positive at about 2 weeks postpartum. Fredriksson and his group had attributed the differences in incidence to various factors such as breed, environment, management procedures and sampling techniques.

It was also observed in the present study that during the second week postpartum, cows with abnormal puerperium had higher incidence of uterine bacterial infection than those with normal puerperium. This agrees with the observation that cows with postpartum disorders have a greater tendency for bacterial infection $[10,29]$. On the fourth week, a decreased incidence of uterine bacterial infection was observed in cows with abnormal puerperium. It was noted that about a third of the cows with normal puerperium had bacterial flora during the second and fourth week postpartum. Although these cows did not have clinical signs of uterine infection, it could indicate the proportion of normal cows that would be susceptible to uterine bacterial contamination.

It is generally considered that the bacterial flora of the postpartum cow uterus follow a predictable transient pattern [10] and that the highest rate of bacterial isolation appears at 2 weeks followed by a gradual decline to a constant rate by 7 weeks [5, 8].

The three common bacterial organisms isolated in the present study were similar with those reported by Studer and Morrow [7] and Torres et al.
[12]. Actinomyces pyogenes was also reported by Noakes et al. [11] as the most common bacterial isolate from postpartum cows. The possible role of $A$. pyogenes infection in cases of postpartum endometritis $[6,7,30]$ and the pathogenic synergism with gram negative anaerobes in severe cases of postpartum uterine infections had been suggested $[5,9,11,13]$.

The effects of stress and the occurrence of uterine bacterial infection were most apparent during the early postpartum period. This could indicate that the increased susceptibility of the uterus to bacterial infection occur during the time when postpartum cows are under a greater degree of stress.

It has already been reported elsewhere $[9,29]$ that postpartum complications and uterine bacterial infections delay the involution of the uterus. Similar findings were observed in this study. Some authors had reported a delayed onset of ovarian activity in cows with endometritis when compared with healthy cows $[31,32]$, however, a similar study by Dohmen et al. [13] found no relationship between bacterial findings and ovarian activity. The present findings tend to support the observations made by the group of Dohmen. It should be recognized that ovarian activity and uterine involution are reported to be influenced by various factors. It may be necessary to evaluate these factors and their intricate relationships as was done by Zain et al. [33].

In conclusion, cows with abnormal puerperium had significantly higher basal plasma cortisol levels during the first week postpartum and higher incidence of uterine bacterial infection during the second week than normal cows. Onset of ovarian activity was apparently affected neither by puerperal disorders nor uterine bacterial infection, whereas uterine involution at 4 weeks postpartum was delayed in about a fourth of abnormal cows.

\section{Acknowledgment}

E. B. Torres was supported by a research fellowship from the Japan Society for the Promotion of Science. The authors wish to thank the staff of the dairy farms of the Rakuno Gakuen University for their help and cooperation in carrying out this experiment. 


\section{References}

1. Alam MGS, Dobson H, Fitzpatrick RJ. Endocrine response to different doses of ACTH in cows. $\mathrm{Br}$ vet J 1986; 142: 239-245.

2. Breazile JE. The physiology of stress and its relationship to mechanisms of disease and therapeutics. Vet Clin North Am: Food Anim Pract 1988; 4: 441-480.

3. Breazile JE. Physiological basis and consequences of distress in animals. J Am Vet Med Assoc 1987; 191: 1212-1215.

4. Vandeplassche M, Bouters R. Puerperal metritis in the bovine. In: Program of 8 th International Congress of Animal Reproduction and Artificial Insemination. 1976; Krakow, Poland. IV: 660-661.

5. Elliott L, McMahon KJ, Gier HT, Marion GB. Uterus of the cow after parturition. Am J Vet Res 1968; 29: 77-81.

6. Griffin JFT, Hartigan PJ, Nunn WR. Non-specific uterine infection and bovine infertility. I. Infection patterns and endometritis during the first seven weeks post-partum. Theriogenology 1974; 1: 91-106.

7. Studer E, Morrow DA. Postpartum evaluation of bovine reproductive potential: Comparison of findings from genital tract examination per rectum, uterine culture, and endometrial biopsy. J Am Vet Med Assoc 1978; 172: 489-494.

8. Ruder CA, Sasser RG, Williams RJ, Ely JK, Bull RC, Butler JE. Uterine infections in the postpartum cow. II. Possible synergistic effect of Fusobacterium necrophorum and Corynebacterium pyogenes. Theriogenology 1981; 15: 573-580.

9. Fredriksson G, Kindahl H, Sandstedt K, Edqvist L-E. Intrauterine bacterial findings and release of PGF2 $\alpha$ in the postpartum dairy cow. Zbl Vet Med A 1985; 32: 368-380.

10. Hussain AM, Daniel RCW, O'Boyle D. Postpartum uterine flora following normal and abnormal puerperium in cows. Theriogenology 1990; 34: 291302.

11. Noakes DE, Wallace L, Smith GR. Bacterial flora of the uterus of cows after calving on two hygienically contrasting farms. Vet Rec 1991; 128: 440-442.

12. Torres EB, Enriquez JB, Vizmanos MFC. Bacteriologic profile of the vagina and uterus of postpartum dairy cows. Phil J Vet Med 1994; 31: 14.

13. Dohmen MJW, Lohuis JACM, Huszenica G, Nagy $\mathbf{P}$, Gacs M. The relationship between bacteriological and clinical findings in cows with subacute/ chronic endometritis. Theriogenology 1995; 43: 1379-1388.

14. Weaver LD. Effects of nutrition on reproduction in dairy cows. Vet Clin North Am: Food Anim Pract 1987; 3: 513-532.

15. National Research Council. Nutrient requirements of Dairy Cattle. 6th ed. Washington, D.C.: National Academy of Science; 1988: 78-115.

16. Buch NC, Tyler WJ, Casida LE. Postpartum estrus and involution of the uterus in an experimental herd of Holstein-Friesian cows. J Dairy Sci 1955; 38: 73-79.

17. Johanns CJ, Clark TL, Herrick JB. Factors affecting calving interval. J Am Vet Med Assoc 1967; 151: 1692-1704.

18. Nakao T, Tamamura F, Tsunoda N, Kawata K. Double antibody enzyme immunoassay of cortisol in bovine plasma. Steroids 1981; 38: 111-120.

19. Nakao T, Grunert E. Postpartum adrenocortical function in dairy cows with dystocia submitted to cesarean section. Theriogenology 1989; 22: 205-209.

20. Nakao T, Grunert E. Effects of dystocia on postpartum adrenocortical function in dairy cows. J Dairy Sci 1990; 73: 2801-2806.

21. Studer E, Morrow DA. Uterine cultures and histological evaluation as complements to routine postpartum examinations. In: Morrow DA (ed.), Current Therapy in Theriogenology: Diagnosis, Treatment and Prevention of Reproductive Diseases in Animals. Philadelphia: W. B. Saunders Co. 1980: 223-226.

22 Carter GR. Diagnostic Procedures in Veterinary Bacteriology and Mycology. 6th ed, Illinois: Charles C. Thomas; 1990: 19-39.

23. Nakao T, Sugihashi A, Saga N, Tsunoda N, Kawata K. An improved enzymeimmunoassay of progesterone applied to bovine milk. Br vet J 1983; 139: 109-118.

24. Stevenson JS, Britt JH. Models for prediction of days to first ovulation based on changes in endocrine and non-endocrine traits during the first two weeks postpartum in Holstein cows. J Anim Sci 1980; 50: 103-112.

25. Smith VG, Edgerton LA, Hafs HD, Convey EM. Bovine serum estrogens, progestins and glucocorticoids during late pregnancy, parturition and early lactation. J Anim Sci 1973; 36: 391-396.

26. Hudson S, Mullford M, Whittlestone WG, Payne E. Bovine plasma corticoids during parturition. J Dairy Sci 1975; 59: 744-746.

27. Kejela G, Head HH, Wilcox CJ, Thatcher WW. Adrenal responsiveness in pre- and postpartum dairy cows. J Dairy Sci 1978; 61: 1736-1741.

28. Heuwieser W, Hartig U, Offeney F, Grunert E. Zur Bedeutung von Glukokortikoiden als Streßparameter beim Rind im peripartalen 
Zeitraum. J Vet Med A 1987; 34: 178-187.

29. Roberts SJ. Veterinary Obstetrics and Genital Diseases. 2nd ed, Ann Arbor, Michigan: Edwards Brothers, Inc.; 1971: 317-336.

30 Griffin JFT, Hartigan PJ, Nunn WR. Non-specific uterine infection and bovine infertility. II. Infection patterns and endometritis before and after service. Theriogenology 1974; 1: 107-114.

31. Borsberry S, Dobson H. Periparturient diseases and their effect on reproductive performance in five dairy herds. Vet Rec 1989; 124: 217-219.

32. Holt LC, Whittier WD, Gwazdauskas FC, Vinson WE. Early postpartum reproductive profiles in Holstein cows with retained placenta and uterine discharges. J Dairy Sci 1989; 72: 533-539.

33. Zain AE-D, Nakao T, Abdel Raouf M, Moriyoshi M, Kawata K, Moritsu Y. Factors in the resumption of ovarian activity and uterine involution in postpartum dairy cows. Anim Reprod Sci 1995; 38: 203-214. 